Original Article

\title{
Fungivory: a new and complex ecological function of Doru luteipes (Scudder) (Dermaptera: Forficulidae)
}

\author{
Fungivoria: uma nova e complexa função ecológica de Doru luteipes (Scudder) \\ (Dermaptera: Forficulidae)
}

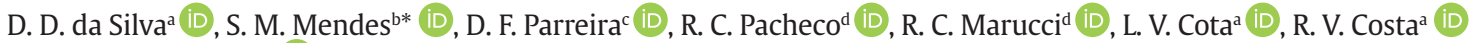 \\ and J. E. F. Figueiredo ${ }^{\text {iD }}$ \\ aEmbrapa Milho e Sorgo, Laboratório de Fitopatologia, Sete Lagoas, MG, Brasil \\ 'Embrapa Milho e Sorgo, Laboratório de Entomologia, Sete Lagoas, MG, Brasil \\ 'Universidade Federal de Viçosa - UFV, Laboratório de Fitopatologia, Rio Paranaíba, MG Brasil \\ dUniversidade Federal de Lavras - UFLA, Departamento de Entomologia, Laboratório de Controle Biológico de Pragas, Lavras, MG, Brasil
}

\begin{abstract}
We report the discovery that the earwig predator Doru luteipes (Scudder, 1876)(Dermaptera: Forficulidae) feed on Puccinia polysora Underw uredospore, the causal agent of Southern Rust of Corn (SRC), which is a primary disease affecting the maize crop in Brazil. We performed experiments in laboratory and greenhouse to test the effect of D. luteipes (1st/2nd and 3rd/4th instars, and adults) fungivory on the P. polysora uredospore concentration. All trials showed a significant reduction of the initial concentration of uredospore. There was a reduction in uredospore concentration with increase in number of $D$. luteipes feeding on them. We also tested the uredospore consumption by quantifying its percentage in the feces of $D$. luteipes. Nymphs of the $2^{\text {nd }}, 4^{\text {th }}$ instar and adults fed $88 \%, 85 \%$, and $83.8 \%$ of the uredospore, respectively. For nymphs of the $3^{\text {rd }}$ instar, the percentage of uredospore consumption (75.6\%) was statistically significant compared with the other groups. In greenhouse experiment, at twenty-eight days after plant inoculation with $9.9 \times 10^{4}$ uredospores, the percentage of uredospore consumption was $81.7 \%$. Our results confirmed the fungivory of $D$. luteipes on $P$. polysora uredospore. This is the first report of $D$. luteipes fungivory, which may play an important role in the biological control of $P$. polysora in corn.
\end{abstract}

Keywords: earwig, southern rust, maize, biological control.

\begin{abstract}
Resumo
Relatamos a descoberta de que o predador Doru luteipes (Scudder, 1876) (Dermaptera: Forficulidae) se alimenta de uredosporos de Puccinia polysora Underw, o agente causal da ferrugem polisora que é uma doença primária que afeta a cultura do milho no Brasil. Realizamos experimentos em laboratório e em casa de vegetação para testar 0 efeito da fungivoria de $D$. luteipes ( $1^{\circ} / 2^{\circ}$ e $3^{\circ} / 4^{\circ}$ ì̀stares e adultos) sobre a concentração de uredosporos de P. polysora. Todos os ensaios mostraram uma redução significativa da concentração inicial de uredosporos. Houve uma redução na concentração de uredosporos com o aumento do número de $D$. luteipes alimentando-se deles. Também testamos o consumo de uredosporos quantificando sua porcentagem nas fezes de $D$. luteipes. Ninfas do $2^{\circ}$ e $4^{0}$ ínstar, assim como adultos, alimentaram-se de $88 \%, 85 \%$ e $83,8 \%$ dos uredosporos, respectivamente. Para ninfas do 3ํ ínstar, a porcentagem de consumo de uredosporos (75,6\%) foi estatisticamente significativo em comparação com os outros grupos. No experimento em casa de vegetação, aos 28 dias após a inoculação das plantas com 9,9 x $10^{4}$ uredosporos, a porcentagem de consumo de uredosporos foi de $81,7 \%$. Nossos resultados confirmaram a fungivoria de $D$. luteipes em uredosporos de $P$. polysora. Este é o primeiro relato de fungivoria de $D$. luteipes, que pode ter papel importante no controle biológico de $P$. polysora em milho.
\end{abstract}

Palavras-chave: tesourinha, ferrugem do milho, milho, controle biológico.

\section{Introduction}

The earwig Doru luteipes (Scudder, 1876) (Dermaptera: Forficulidae) is the most common insect predator found in cornfields in Brazil (Cruz, 1995; Cruz and Oliveira, 1997). The nymph stage of earwig lasts approximately 40 days, and the adults can live up to one year (Reis et al., 1988).
The longevity of $D$. luteipes protects the maize plants against almost all insect pests during the crop season (Cruz, 1995). Doru luteipes is insect is a voracious predator and can eat up to 21 first instar larvae of Spodoptera frugiperda (Smith, 1797) (Lepidoptera: Noctuidae) per

*e-mail: simone.mendes@embrapa.br

Received: May 27, 2020 - Accepted: July 20, 2020 
day (Reis et al., 1988). Doru luteipes is attracted by volatile organic compounds produced by maize plants attacked by S. frugiperda and Diatraea saccharalis (Fabricius, 1794) (Lepidoptera: Crambidae) (Naranjo-Guevara et al., 2017). The ability to feed on corn pollen enables $D$. luteipes to survive under the low availability of prey. This situation strongly evidences the relationship between this predatory species and the maize plants (Marucci et al., 2019).

Among fungal diseases, the southern rust of corn (SRC) caused by Puccinia polysora (Underw) is widely distributed throughout the corn-growing areas of Brazil and can cause up to 65\% yield loss (Costa et al., 2010; Dudienas et al., 2013; Moratelli et al., 2015; Amorim et al., 2016; Juliatti et al., 2016). Under favorable environmental conditions, the fungus produces teliospores and uredospores, which are the primary and secondary sources of inoculum of the disease (Casela and Ferreira, 2002). Nevertheless, the high genetic variability of the pathogen and the breakdown of plant resistance by $P$. polysora impose the necessity for searching alternative approaches to reduce the disease incidence in cornfields (Waquil et al., 2002; Godoy et al., 2003).

Fungivory is an essential characteristic of many insects that remains relatively under-explored for biological control (Lawrence, 1989; Lundgren, 2009; Schickmann et al., 2012; Yamashita et al., 2015). For instance, the orders Coleoptera and Diptera have the highest number of known fungivorous species (Hanski, 1989; Komonen, 2003; Amat-García et al., 2004; Yamashita et al., 2015) followed by the orders Lepidoptera and Hymenoptera (Jonsell et al., 2001) and |Dermaptera (Chen et al., 2014; Paula et al., 2016).

In the family Coccinellidae, many species have been described as facultative fungivorous (tribes Coccinellini and Tytthaspidini), while in the cosmopolitan tribe Halyziini all members are specialized in feeding on powdery mildew fungi of Erysiphales (Sutherland and Parrella, 2009). Another study, Mondy and Corio-Costet (2004), reported that larvae of the European grapevine moth, Lobesia botrana (Denis \& Schiffermüller, 1775) (Lepidoptera: Tortricidae) fed with the phytopathogenic fungus Botrytis cinerea Persoon:Fries (Sclerotiniaceae) showed a high survival rate, increased fecundity, and accelerated the larval development. Altogether, the interspecific relationship between fungi, insects, and plants suggests that the fungivory attribute of some insects may be useful for biological control of fungal pathogens. Thus, this approach associated with sustainable integrated management strategies may reduce the use of fungicides for controlling fungal diseases in plants (Mondy and CorioCostet, 2004; Cividanes et al., 2007; Tabata et al., 2011).

Given the possibility of fungivory by $D$. luteipes, we point out the following questions: $i$ ) Does $D$. luteipes feed on P. polysora uredospores?; $i i$ ) What is the consumption of uredospores by nymphs and adults of $D$. luteipes?; iii) Does exist a correlation between the increase in density of $D$. luteipes and the increase of uredospores consumption? In the present study, we tested the fungivory hypothesis by $D$. luteipes feeding on P. polysora uredospores.

\section{Materials and Methods}

The mycophagy behavior of $D$. luteipes feeding on $P$. polysora uredospores was tested in laboratory and greenhouse experiments. The experiments were carried out at the Entomology and Phytopathology laboratories and in the greenhouse at the Embrapa Milho e Sorgo, Sete Lagoas, Minas Gerais State. All material used in the experiments was washed with a solution of $0.1 \%$ Tween 20 in $200 \mathrm{~mL}$ water $(\mathrm{v} / \mathrm{v})$, and the maize leaves were disinfected with $70 \%$ ethyl alcohol. Five days old adult insects were after the last nymph ecdysis.

Production and quantification of uredospores of P. polysora. A monopustular isolate of $P$. polysora obtained from the Multifunctional and Phytopathogenic Microorganism Collection (CMMF) of the Embrapa Milho e Sorgo was multiplied in a greenhouse. The uredospore production was achieved by inoculating plants of the susceptible maize hybrid BRS1010 on the $15^{\text {th }}$ day after plant emergency (DAE) in the concentration of $1 \times 10^{4}$ uredospores/mL, calibrated using a Neubauer Chamber (Figure 1A). The analysis of the number of spores in each experiment's treatment was done by washing the used materials: leaves, moisten cotton, Petri dishes, D. luteipes and plastic containers, using Tween 20 at $0.1 \%$ until it reaches $200 \mathrm{~mL}$. The spore concentration was obtained by counting in a Neubauer chamber.

Insect rearing. The rearing of $D$. luteipes was performed at the Insects and Management Ecotoxicology Laboratory of Embrapa Milho e Sorgo according to the methodology proposed by Souza et al. (2019), that uses groups about 50 insects per cage and diet made of cat food (35\%), wheat bran (27\%), beer yeast (23\%), powdered milk (14\%), nipagine (5\%) and ascorbic acid (5\%). The insects were multiplied and maintained at a temperature of $25^{\circ} \mathrm{C} \pm 2$ with $70 \%$ relative humidity, and 12 hours photophase, in this rearing insects form the field are added each 6 months. The insects used in the experiments were adults up to five days after the last ecdysis.

Doru luteipes feeding the P. polysora uredospores in the laboratory. The experiment to test the $D$. luteipes feeding on $P$. polysora uredospores consisted of two treatments,

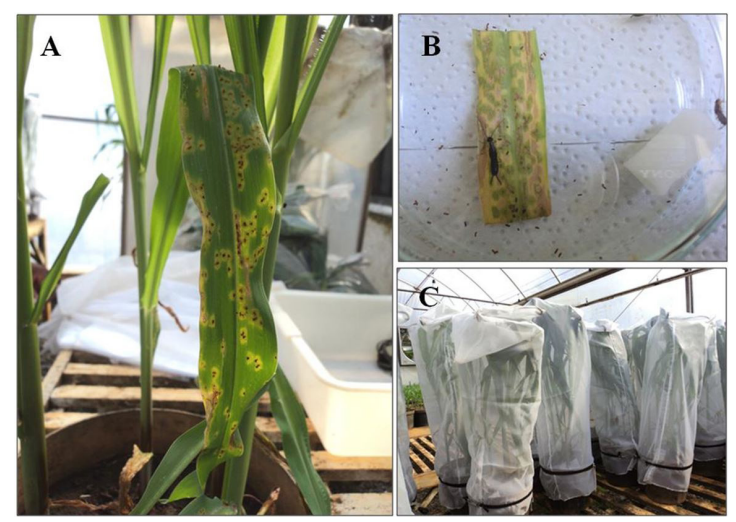

Figure 1. Greenhouse and laboratory experiments for testing Doru luteipes feeding on Puccinia polysora uredospores. Panel (A) and $(C)$ depicts the general aspects of a maize plant infected with $P$. polysora, and (B) show D. luteipes feeding P. polysora uredospores in Petri dishes. 
each with ten replicates and negative control (absence of $D$. luteipes) and ten with one adult individual of $D$. luteipes per Petri dish. Before the tests, the insects were fasted for $24 \mathrm{~h}$ to starve them. Pieces of $5 \times 5 \mathrm{~cm}$ of the third and fourth leaves above the first internode of maize plants with $P$. polysora pustules were placed in twenty $10 \mathrm{~cm}$ diameter Petri dishes (2 cm deep) (Figure 1B). A piece of cotton moistened with sterile distilled water was put into each Petri dish to provide water for $D$. luteipes. Afterward, the dishes were kept at $25^{\circ} \mathrm{C} \pm 2$ for $48 \mathrm{~h}$, followed by the quantification of consumed spore. The quantification of the consumed uredospores was performed by comparing the number of spores on the leaves of the controls and the leaves submitted to feeding by $D$. luteipes.

Doru luteipes feeding the P. polysora uredospores in the greenhouse. The maize hybrid BRS 1010, susceptible to $P$. polysora, was planted in forty 20 liters plant pots containing a soil and sand (1:1) mixture and then kept in the greenhouse. The plants were thinned to two plants per pot, and 15 days later, after sprouting, they were inoculated with a $P$. polysora uredospore suspension of $1 \times 10^{4}$ uredospores $/ \mathrm{mL}$. At three days after inoculation, the pots were separated in two treatments: 20 pots received two adult individuals of $D$. luteipes, and 20 were kept without insects (negative control). Afterward, all pots were covered with insect nets to prevent insects from escaping or entering the pots (Figure $1 \mathrm{C}$ ). At 30 days, the aerial parts of the plants were collected in plastic bags containing $200 \mathrm{~mL}$ of $0.1 \%$ Tween-20 (v/v) and vigorously agitated. The uredospores concentration was determined in the laboratory.

Quantification of the P. polysora uredospores consumption by $D$. luteipes in the laboratory. Puccinia polysora uredospores collected from maize plants grown in the greenhouse were stored in $1.5 \mathrm{~mL}$ capacity Eppendorf tubes and stored at $4-8^{\circ} \mathrm{C}$. The number of uredospores per gram was standardized by weighing and counting in a Neubauer chamber. The value obtained showed that $0.024 \mathrm{~g}$ of uredospores corresponded to approximately $8.1 \times 10^{6}$ uredospores/mL. Sixty $50 \mathrm{~mL}$ plastic boxes containing $0.024 \mathrm{~g}$ of uredospores each, and a piece of water-moistened cotton were separated in three treatments. Twenty boxes containing uredospores without insect were used as negative controls: 20 boxes with one individual of $D$. luteipes in the $1^{\text {th }}$ or $2^{\text {th }}$ instar, and 20 boxes with one $D$. luteipes in the $3^{\text {th }}$ or $4^{\text {th }}$ instar. The assessment was done using groups of $1^{\text {th }}$ or $2^{\text {th }}$ instar and, $3^{\text {th }}$ or $4^{\text {th }}$ instar because some insects went by ecdise during the period. After five days, the boxes were washed to count the remaining uredospores and to estimate the uredospores consumption by $D$. luteipes.

Effect of $D$. luteipes density on $P$. polysora uredospores concentration. Sixty $10-\mathrm{cm}$ diameter Petri dishes, each containing a piece of water-moistened cotton and a $5 \times 5 \mathrm{~cm}$ leaf fragment with $P$. polysora pustules, were separated into three treatments: 20 Petri dishes without insects used as negative controls, 20 plates with two, and 20 with four adults of $D$. luteipes. Afterward, the treatments were kept at $25^{\circ} \mathrm{C} \pm 2$ for $48 \mathrm{~h}$. Before the test, the insects were starved for $24 \mathrm{~h}$. The spore quantification assay was performed as follows: Petri dishes with their respective treatments were washed with $200 \mathrm{~mL}$ of $0.1 \%$ Tween-20, and the uredospores were counted in a Neubauer chamber.

Effect of the D. luteipes feeding time on spore concentration of $P$. polysora. Forty-two 20 liters vases with a 1:1 mixture of soil and sand were used to plant BRS 1010 hybrids in the greenhouse. After the emergency period, two small plants were kept in each vase, and the inoculation was made at the $15^{\text {th }} \mathrm{DAE}$ with the suspension of $1 \times 10^{4} \mathrm{P}$. polysora uredospore $/ \mathrm{mL}$. Three days after the inoculation (18 DAI), the vases were separated into two treatments: 21 vases had two adult $D$. luteipes individuals, and 21 vases were kept without insects as a negative control. After release, all 42 vases were covered with a cage to avoid the movement of insects between vases and external interference. Three severity evaluations were made using note scale (AGROCERES, 1996), followed by the collection of the plants at the 23,28 , and 33 DAE, using seven vases per treatment in each evaluation. For each evaluation, the aerial part of 14 plants was collected and put into plastic bags containing $200 \mathrm{~mL}$ of Tween 20 at $0.1 \%$. The bags were shaken, and the concentration of uredospore quantified using a Neubauer chamber.

Quantification of the uredospores of $P$. polysora in feces of $D$. luteipes. In this experiment, forty nymphs from each instar and adults (males and females) were placed in separate boxes of $50 \mathrm{~mL}$ capacity, containing moistened cotton, and fasted for 48 hours. After this period, the insects were transferred to containers $(500 \mathrm{~mL})$ containing moistened cotton and $P$. polysora uredospores in paper forms $(3 \mathrm{~cm})$ sealed with cotton voille. For ad libitum, the insects were feeding for 24 hours. Then, the remaining uredospores not consumed were collected and quantified. The feces of each set of ten individuals (nymphs of each instar and adults) were collected to verify the presence of uredospores, resulting in four replicates. The feces were weighed, macerated with the aid of a glass stick, and transferred to a test tube containing $9 \mathrm{~mL}$ of Tween 80 surfactant solution, stirred for three minutes to break up the uredospores mass. The uredospores present in the feces were quantified by counting in the Neubauer chamber to determine the percentage of consumption concerning the total initially offered to the insects. The germination capacity of the uredospores after passing through the digestive tract of the earwigs was evaluated by plating $1 \mathrm{ml}$ of the uredospores suspension recovered from the feces, in agar-agar medium and kept for 12 hours in a growth chamber. After this period, the uredospores were evaluated under an optical microscope.

Statistical analysis. The data were submitted to analysis of variance (ANOVA) and the means compared by the Tukey test at $5 \%$ of probability. When necessary, the data were transformed into the square root of $Y+1.0$ - SQRT (Y+1.0) to attend the requirements of the analysis of variance (ANOVA). Correlation analysis was performed to assess the effect of the number of insects on the consumption of supplied uredospores. The statistical analysis, data transformation, and graphics were performed by using the statistical analysis software SISVAR®-Version 5.3 (Ferreira, 2011). 


\section{Results}

In the experiments in the laboratory to test the $D$. luteipes feeding on $P$. polysora uredospores, the lower concentration of uredospores ( $3.81 \times 10^{-4}$ uredospores $/ \mathrm{mL}$ ) was observed in the treatment with $D$. luteipes, which differed statistically (Fc: 6.636; GL: 19; P-value: 0.027 CV\%: 11.56) from the controls (5.32 x 10-4 uredospores/mL) (Figure 2A).

In the experiment under greenhouse conditions, the uredospores concentration of $3.95 \times 10^{-4}$ uredospores/mL observed in the treatment with $D$. luteipes differed statistically (Fc: 6.896; GL: 38; P-value: 0.0124; CV\%: 11.43) from the

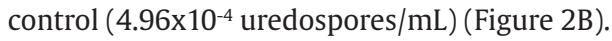

In the laboratory experiment for quantifying uredospores consumption by $D$. luteipes, the treatments with $1^{\text {st }} / 2^{\text {nd }}$ and $3^{\text {rd }} / 4^{\text {th }}$ instars showed the lowest uredospore averages. The insects consumed approximately $31 \%$ and $35 \%$ of the uredospores, respectively. The result was
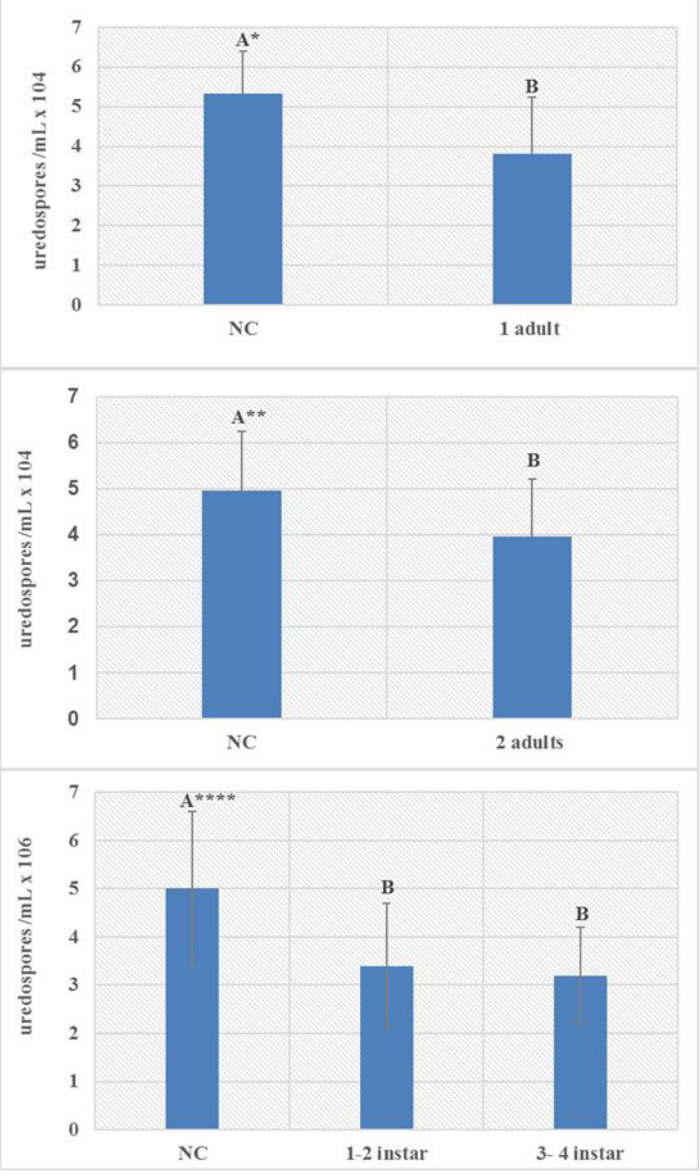

Figure 2. Effects of the number of individuals and the developmental stage of Doru luteipes on Puccinia polysora uredospore concentration ( \pm standard deviation). One adult of $D$. luteipes (A) and two adults of $D$. luteipes (B) feeding on $P$. polysora uredospore and (C) developmental stage of Doru luteipes on Puccinia polysora uredospore concentration. Columns followed by the same capital letter do not differ by the Tukey test $(\mathrm{P}<0.05)$. $\mathrm{NC}=$ negative control. ${ }^{*}$ P-value $\leq 0,05,{ }^{* *}$ P-value $\leq 0,01,{ }^{* * *} \mathrm{P}$-value $\leq 0,001$. statistically different from the controls, but not from each other (Fc: 13.427; GL: 59; P-value: 0.0000; CV\%: 6.54) (Figure 2C).

In the greenhouse experiment to evaluate the effect of the feeding period of $D$. luteipes over the concentration of P. polysora uredospores, there was a significant interaction between the evaluation periods and treatments on the uredospore concentration (Fc: 3.73; GL: 36; P-value: 0.034; CV\%: 39.82) (Table 1). The regression analysis with the number of earwigs and uredospores (Figure 3 ) corroborated the other results of this study. It confirmed that the number of $D$. luteipes individuals was strictly connected with reducing the number of uredospores of $P$. polysora.

We found that both nymphs $\left(2^{\text {nd }}, 3^{\text {rd }}\right.$, and $4^{\text {th }}$ instars $)$ and adults of $D$. luteipes consumed the $P$. polysora uredospores by counting the uredospores in the feces (Table 2). Nymphs of $2^{\text {nd }}$ and $4^{\text {th }}$ instars showed a significantly higher percentage of consumption compared to 3rd instar nymphs (Fc: 11.195; GL: 11; P-value: 0.0072; CV\%: 3.76). For firstinstar nymphs, it was impossible to count the number of uredospores due to the small number of feces produced.

The uredospores recovered from the feces of nymphs and adults did not germinate in a culture medium containing water-agar (Table 2). Most of the uredospores had their cell wall broken when they passed through the digestive tract of $D$. luteipes, which explains the absence of germination.

\section{Discussion}

The results of all experiments demonstrated the consumption of $P$. polysora uredospores by $D$. luteipes. These results confirmed our previous empirical observations on $D$. luteipes feeding on $P$. polysora uredospores in the greenhouse.

Several studies have indicated that the fungal sporulation rate in the host plant is a parameter for evaluating the plant resistance to diseases (Parlevliet, 1979; Delmas et al., 2016). In analogy to this concept, although D. luteipes did not directly reduce the rate of pathogen sporulation, it controlled the number of uredospores on the leaf lesions. This result suggests that $D$. luteipes may reduce the inoculums potential and disease epidemic in corn crops.

Tabata et al. (2011) also reported insect fungivory with greater emphasis on ladybugs predating powdery mildews. Fungi represent a nutrient-rich diet with many nutritional attributes as high amino acid content, vitamins, and minerals necessary for optimizing the entomophagous lifehistory traits (Martin, 1979; Mondy and Corio-Costet, 2004; Douglas, 2015). Studies by Sutherland and Parrella (2009) on insect fungivory concluded that this is the primary component for the natural control of fungal diseases in plants. In ladybugs Psyllobora vigintimaculata (Say, 1824) (Coleoptera: Coccinellidae), both the food specificity and aggregation in response to the population density of the fungus infecting a plant are desirable characteristics for biological control of powdery mildews. A positive effect of the fungivorous insect Psyllobora bisoctonotata (Mulsant, 1850) (Coleoptera: Coccinellidae) feeding on powdery mildews was also documented in Sudan (Satti, 2013). In 
Table 1. Effect of Doru luteipes adults feeding on Puccinia polysora uredospores at different times in a greenhouse.

\begin{tabular}{lcccc}
\hline \multirow{2}{*}{ Treatment } & \multicolumn{3}{c}{ Evaluation dates } & Mean \\
\cline { 2 - 4 } & 23 DAE & 28 DAE & 33 DAE & $15.4 \pm 1.4 \mathrm{a}$ \\
\hline Negative Control & $15.7 \pm 1.9 \mathrm{aA}$ & $18.3 \pm 2.7 \mathrm{aA}$ & $12.2 \pm 2.1 \mathrm{aA}$ & $11.9 \pm 1.4 \mathrm{~b}$ \\
Doru luteipes & $18.4 \pm 1.9 \mathrm{aA}$ & $9.9 \pm 2.1 \mathrm{bB}$ & $7.6 \pm 1.4 \mathrm{aB}$ & \\
Mean & $17.0 \pm 1.3 \mathrm{~A}$ & $14.1 \pm 2.0 \mathrm{AB}$ & $9.9 \pm 1.4 \mathrm{~B}$ & \\
\hline
\end{tabular}

Averages ( \pm standard error) followed by the same capital letters in the column and lowercase in the row do not differ by the Tukey test $(\mathrm{P}<0.05)$. Inoculum concentration $\left(1 \times 10^{4}\right.$ uredospores $\left./ \mathrm{mL}\right) ; \mathrm{DAE}=$ days after emergence.

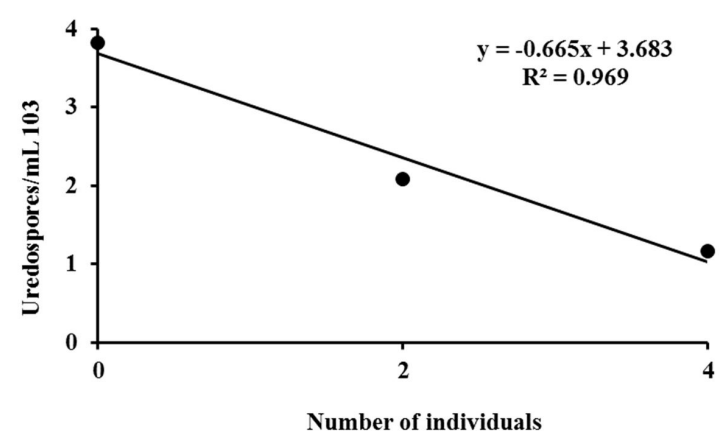

Figure 3. In vitro effect on Puccinia polysora uredospores concentration determined by the number of Doru luteipes individuals feeding on it.

Brazil, Psyllobora rufosignata (Mulsant, 1851)(Coleoptera: Coccinellidae) feeding on uredospores from vine rust (Phakopsora euvitis Diet. \& Syd) was reported by Culik et al. (2011).

The presence of $D$. luteipes feeding preys and pollen have been documented throughout the year in all Brazilian maize-growing areas (Reis et al., 1988; Marucci et al., 2019), which reinforces its omnivorous behavior. Considering the high uredospore consumption rate and the absence of germination of uredospores recovered from the feces. We assume that $D$. luteipes feeding on $P$. polysora uredospores is a feature to be explored to reduce the inoculum source of southern rust disease in the field. Thus, field studies are necessary to determine the potential of $D$. luteipes for reducing the damages to maize crops caused by P. polysora. According to Pinho et al. (1999), the maize grain yield losses can reach up to $40 \%$ in susceptible genotypes during environmental conditions favorable for the southern rust disease development. In the greenhouse, a direct connection existed between the increased number of $D$. luteipes and the reduction of $P$. polysora uredospores. However, integrated management practices using $D$. luteipes for controlling SRC need to prevent the harmful effects of insecticides on the predator population. Thus, it is crucial to develop strategies to facilitate the $D$. luteipes fungivory and the use of selective insecticides affecting only the target pest populations. In a study to test the effects of different insecticides on D. luteipes, Campos et al. (2011) found that the insecticides used for controlling the insect pest S, frugiperda (Smith, 1797) (Lepidoptera: Noctuidae) showed low toxicity against the non-target $D$. luteipes.

To date, the transmission of $P$. polysora by insects was reported by Turner (1974) and involved Aphis dorsata (Fabr., 1793) (Hymenoptera: Apidae) after visiting corn plants with a high incidence of rust on leaves and stems. We reported the capacity of $D$. luteipes to reduce uredospores of $P$. polysora in vitro and greenhouse. We also verified that there was no germination of spores recovered from the feces of $D$. luteipes. In another study, Chen et al. (2014) reported that the passage of spores from the fungus Lysurus mokusin (Linnaeus) Fries through the gut of Anisolabis maritima earwigs (Bonelli, 1832) (Dermaptera: Anisolabididae) significantly enhanced the germination rate of spores. The authors concluded that dispersal via feces plays a vital role in the dispersal of L. mokusin spores.

Doru luteipes feeding on $P$. polysora uredospores reduces the number of fungal structures and cause rupture in the cell wall. However, some uredospores showed no disruption of the cell wall. Studies are necessary to prove the occurrence of spore dispersal of $P$. polysora in the field. Chen et al. (2014) reported for A. maritima, there was an increase in spore germination in feces.

Table 2. Average number ( \pm standard error) of Puccinia polysora uredospores in the diet and feces and percentage of consumption ( \pm standard error) of uredospores by Doru luteipes.

\begin{tabular}{lccc}
\hline \multicolumn{1}{c}{ Treatments } & Uredospores/mL diet & Uredospores/mL feces & \% consumption \\
\hline $2^{\text {nd }}$ instar & $3.8 \pm 0.1 \times 10^{4}$ & $0.4 \pm 0.5 \times 10^{4}$ & $88.6 \pm 1.80 \mathrm{a}$ \\
$3^{\text {rd }}$ instar & $3.8 \pm 0.1 \times 10^{4}$ & $0.9 \pm 0.5 \times 10^{4}$ & $75.6 \pm 0.96 \mathrm{~b}$ \\
$4^{\text {th }}$ instar & $10.0 \pm 0.4 \times 10^{4}$ & $1.2 \pm 1.8 \times 10^{4}$ & $88.5 \pm 2.19 \mathrm{a}$ \\
Adults & $10.0 \pm 0.4 \times 10^{4}$ & $1.4 \pm 1.9 \times 10^{4}$ & $83.8 \pm 1.08 \mathrm{ab}$ \\
Positive control & -- & -- & \\
Negative control & & & \\
\hline
\end{tabular}

Averages followed by the same letters do not differ by the Tukey test $(\mathrm{P}<0.05)$. 
Insects can benefit from feeding fungal structures without dispersing spores (Souza et al., 2019). Also, a mutualistic relationship may occur in which the association benefits both the insect and fungus. Considering that both relationships are relevant for biological pest control, these aspects need to be investigated in the case of $D$. luteipes and $P$. polysora. The results of our work demonstrated the potential use of $D$. luteipes as a biological agent for controlling the Southern rust of corn, which may consequently reduce the number of fungicides applied in cornfields. Besides, $D$. luteipes has been maintained in the laboratory for many generations, allowing its large-scale production to supply the needs of biological control programs.

We described for the first time the $D$. luteipes fungivory reducing the $P$. polysora uredospore-density. This attribute of $D$. luteipes may help develop disease management strategies for reducing the SRC disease incidence in the field.

\section{Acknowledgements}

The authors are thankful to FAPEMIG and Embrapa Milho e Sorgo for financial support, Clovis Geraldo Ribeiro, Daniel França Vasconcellos and Eustáquio Francisco de Oliveira for technical support.

\section{References}

AGROCERES, 1996. Guia Agroceres de Sanidade. 2. ed. São Paulo: Sementes Agroceres. 72 p.

AMAT-GARCÍA, G.D., BLANCO-VARGAS, E. and REYES-CASTILLO, P., 2004. Lista de especies de los escarabajos pasálidos (Coleoptera: Passalidae) de Colombia. Biota Colombiana, vol. 5, no. 2, pp. 173-182.

AMORIM, L., REZENDE, J.A.M. and CAMARGO, L.F.A., 2016. Manual de fitopatologia: doenças das plantas cultivadas. 5. ed. São Paulo: Agronômica Ceres, vol. 2, 810 p.

CAMPOS, M.R., PICANÇO, M.C., MARTINS, J.C., TOMAZ, A.C. and GUEDES, R.N.C., 2011. Insecticide selectivity and behavioral response of the earwig Doru luteipes. Crop Protection (Guildford, Surrey), vol.30, no. 12, pp. 1535-1540. http://dx.doi.org/10.1016/j. cropro.2011.08.013.

CASELA, C.R. and FERREIRA, A.S., 2002. Variability in isolates of Puccinia polysora in Brazil. Fitopatologia Brasileira, vol. 27, no. 4, pp. 414-416. http://dx.doi.org/10.1590/S010041582002000400015 .

CHEN, G., ZHANG, R.R., LIU, Y. and SUN, W.B., 2014. Spore dispersal of fetid Lysyrus mokusin by feces of mychophagous insects. Journal of Chemical Ecology, vol. 40, no. 8, pp. 893-899. http:// dx.doi.org/10.1007/s10886-014-0481-6. PMid:25064696.

CIVIDANES, T.M.S., CIVIDANES, F.J. and MATOS, B.A., 2007. Biologia de Psyllobora confluens alimentada com o fungo Erysiphe cichoracearum. Pesquisa Agropecuária Brasileira, vol. 42, no. 12, pp. 1675-1679. http://dx.doi.org/10.1590/S0100204X2007001200002.

COSTA, R.V., COTA, L.V., SILVA, D.D., PARREIRA, D.F., ROCHA, L.M.P., GUIMARÃES, L.J.M., GUIMARÃES, P.E., PARENTONI, S.N. and MACHADO, J.R.A., 2010. Epidemias severas da ferrugem polissora do milho na região sul do Brasil na safra 2009/2010. Sete Lagoas: Embrapa-CNPMS, pp. 1-23, Circular Técnica, no. 138.
CRUZ, I. and OLIVEIRA, A.C., 1997. Flutuação populacional do predador Doru Luteipes Scudder em plantas de milho. Pesquisa Agropecuária Brasileira, vol. 32, no. 4, pp. 363-368.

CRUZ, I., 1995. Manejo integrado de pragas de milho com ênfase para o controle biológico. Anais da Sociedade Entomológica do Brasil, vol. 24, no. 4, pp. 48-92.

CRUZ, I., 2009. Métodos de criação de agentes entomófagos de Spodoptera frugiperda (J.E. Smith). In: V.H.P. BUENO, ed. Controle biológico de pragas: produção massal e controle de qualidade. Lavras: UFLA, pp. 111-135.

CULIK, M.P., VENTURA, J.A., DE ALMEIDA, L.M. and CORRÊA, G.H., 2011. Feeding by the coccinellid Psylobora rufosignata (Coleoptera: Coccinellidade) on the Asian grapevine leaf rust fungus Phakopsora euvitis (Basidiomycota: Uredinales). Biocontrol Science and Technology, vol. 21, no. 2, pp. 235-238. http://dx.doi.org/10.1080/09583157.2010.538668.

DELMAS, C.E., FABRE, F., JOLIVET, J., MAZET, I.D., RICHART CERVERA, S., DELIÈRE, L. and DELMOTTE, F., 2016. Adaptation of a plant pathogen to partial host resistance: selection for greater aggressiveness in grapevine downy mildew. Evolutionary Applications, vol.9, no. 5, pp. 709-725. http://dx.doi.org/10.1111/ eva.12368. PMid:27247621.

DOUGLAS, A.E., 2015. Multiorganismal insects: diversity and function of resident microorganisms. Annual Review of Entomology, vol. 60, no. 1, pp. 17-34. http://dx.doi.org/10.1146/annurevento-010814-020822. PMid:25341109.

DUDIENAS, C., FANTIN, G.M., DUARTE, A.P., TICELLI, M., BÁRBARO, I.M., FREITAS, R.S., LEÃO, P.C.L., CAZENTINI FILHO, G., BOLONHEZI, D. and PÂNTANO, A.P., 2013. Severidade de ferrugem polissora em cultivares de milho e seu efeito na produtividade. Summa Phytopathologica, vol. 39, no. 1, pp. 16-23. http://dx.doi. org/10.1590/S0100-54052013000100003.

FERREIRA, D.F., 2011. Sisvar: a computer statistical analysis system. Ciência e Agrotecnologia, vol. 35, no. 6, pp. 1039-1042. http:// dx.doi.org/10.1590/S1413-70542011000600001.

GODOY, C.V., AMORIM, L., BERGAMIN FILHO, A., SILVA, H.P., SILVA, W.J. and BERGER, R.D., 2003. Temporal progress of southern rust in maize under different environmental conditions. Fitopatologia Brasileira, vol.28, no. 3, pp. 273-278. http://dx.doi.org/10.1590/ S0100-41582003000300008.

HANSKI, I., 1989. Fungivory: fungi, insects and ecology. In: N. WILDING, N.M. COLLINS, P.M. HAMMOND and J.F. WEBBER, eds. Insect-Fungus interactions. London: Academic Press, pp. 25-68. http://dx.doi.org/10.1016/B978-0-12-751800-8.50008-2.

JONSELL, M., NORDLANDER, G. and EHNSTRÖM, B., 2001. Substrate associations of insects breeding in fruiting bodies of wooddecaying fungi. Ecological Bulletins, vol. 49, pp. 173-194.

JULIATTI, F.C., FIGUEIRÓ, A.A. and ALVES, E.O., 2016. Severity evaluation methods for southern polysora corn rust. Bioscience Journal, vol. 32, no. 4, pp. 969-977. http://dx.doi.org/10.14393/ BJ-v32n4a2016-33730.

KOMONEN, A., 2003. Hotspots of insect diversity in boreal forests. Conservation Biology, vol. 17, no. 4, pp. 976-981. http://dx.doi. org/10.1046/j.1523-1739.2003.02076.x.

LAWRENCE, J.F., 1989. Mycophagy in the Coleoptera: feeding strategies and morphological adaptations. In: N. WILDING, N.M. COLLINS, P.M. HAMMOND and J.F. WEBBER, eds. Insect-Fungus interactions. London: Royal Entomological Society of London, pp 1-23. http://dx.doi.org/10.1016/B978-0-12-751800-8.50007-0.

LUNDGREN, J.G., 2009. Mycophagy. In: J.G. LUNDGREN, ed. Relationships of natural enemies and non-prey foods: progress in biological control. Washington: Springer Science and Business Media, pp. 243-258. http://dx.doi.org/10.1007/978-1-4020-9235-0. 
MARTIN, M.M., 1979. Biochemical implications of insect mycophagy. Biological Reviews of the Cambridge Philosophical Society, vol. 54, no. 1, pp. 1-21. http://dx.doi.org/10.1111/j.1469-185X.1979. tb00865.x.

MARUCCI, R.C., SOUZA, I.L., SILVA, L.O., AUAD, A.M. and MENDES, S.M., 2019. Pollen as a component of the diet of Doru luteipes (Scudder, 1876) (Dermaptera: forficulidade). Brazilian Journal of Biology = Revista Brasileira de Biologia, vol. 79, no. 4, pp. 584-588. http://dx.doi.org/10.1590/1519-6984.184072. PMid:30365637.

MONDY, N. and CORIO-COSTET, M.-F., 2004. Feeding insects with a phytopathogenic fungus influences their diapause and population dynamics. Ecological Entomology, vol. 29, no. 6, pp. 711-717. http://dx.doi.org/10.1111/j.0307-6946.2004.00642.x.

MORATELLI, G., KAEFER, K.A.C., ERTEL, F., VOGT, R.T., FERREIRA, S.D., EGEWARTH, V.A., MATTEI, E., ROSA, W.B. and EGEWARTH, J.F., 2015. Effect of fungicide application times in the control management of leaf foliar diseases in maize. African Journal of Agricultural Research, vol. 10, no. 38, pp. 3686-3695. http:// dx.doi.org/10.5897/AJAR2015.9984.

NARANJO-GUEVARA, N., PEÑAFLOR, M.F.G., CABEZAS-GUERRERO, M.F. and BENTO, J.M.S., 2017. Nocturnal herbivore-induced plant volatiles attract the generalist predatory earwig Doru luteipes Scudder. Naturwissenschaften, vol. 104, no. 9-10, pp. 77. http://dx.doi.org/10.1007/s00114-017-1498-9. PMid:28871442.

PARLEVLIET, J.E., 1979. Components of resistance that reduce the rate of epidemic development. Annual Review of Phytopathology, vol. 17, no. 1, pp. 203-222. http://dx.doi.org/10.1146/annurev. py.17.090179.001223.

PAULA, D.P., LINARD, B., CRAMPTON-PLATT, A., SRIVATHSAN, A., TIMMERMANS, M.J.T.N., SUJII, E.R., PIRES, C.S.S., SOUZA, L.M., ANDOW, D.A. and VOGLER, A.P., 2016. Uncovering Trophic Interactions in Arthropod Predators through DNA Shotgun-Sequencing of Gut Contents. PLoS One, vol. 11, no. 9, pp. 1-14. http://dx.doi.org/10.1371/journal.pone.0161841. PMid:27622637.

PINHO, R.G.V., RAMALHO, M.A.P., SILVA, H.P., RESENDE, I.C. and POZAR, G., 1999. Danos causados pelas ferrugens polissora e tropical no milho. Fitopatologia Brasileira, vol. 24, no. 3, pp. 400-409.
REIS, L.L., OLIVEIRA, L.J. and CRUZ, I., 1988. Biologia e potencial de Doru luteipes no controle de Spodoptera frugiperda. Pesquisa Agropecuária Brasileira, vol. 23, no. 4, pp. 333-342.

SATTI, A.A., 2013. First record and bionomics of the mycophagous ladybird Psyllobora bisoctonotata (Mulsant) (Coleoptera: Coccinellidae) in Sudan. Journal of the Saudi Society of Agricultural Sciences, vol. 14, no. 1, pp. 48-53. http://dx.doi.org/10.1016/j. jssas.2013.06.003.

SCHICKMANN, S., URBAN, A., KRÄUTLER, K., NOPP-MAYR, U. and HACKLÄNDER, K., 2012. The interrelationship of mycophagous small mammals and ectomycorrhizal fungi in primeval, disturbed and managed Central European mountainous forests. Oecologia, vol. 170, no. 2, pp. 395-409. http://dx.doi. org/10.1007/s00442-012-2303-2. PMid:22466900.

SOUZA, C., REDOAN, A., RIBEIRO, C., CRUZ, I., CARVALHO, G. and MENDES, S., 2019. Controle biológico: qual espécie de tesourinha consome mais lagartas e pode ser menos sensivel à exposição a inseticidas? Sete Lagoas: Embrapa Milho e Sorgo. Boletim de Pesquisa e Desenvolvimento, no. 188.

SUTHERLAND, A.M. and PARRELLA, M.P., 2009. Mycophagy in Coccinellidae: review and synthesis. Biological Control, vol. 51, no. 2, pp. 284-293. http://dx.doi.org/10.1016/j. biocontrol.2009.05.012.

TABATA, J., DE MORAES, C.M. and MESCHER, M.C., 2011. Olfactory cues from plants infected by powdery mildew guide foraging by a mycophagous ladybird beetle. PLoS One, vol. 6, no. 8, pp. e23799. http://dx.doi.org/10.1371/journal.pone.0023799. PMid:21876772.

TURNER, G.J., 1974. Possible transmission of Puccinia polysora by bees. Transactions of the British Mycological Society, vol. 62, no. 1, pp. 205-206. http://dx.doi.org/10.1016/S0007-1536(74)80022-7.

WAQUIL, J.M., VIANA, P.A. and CRUZ, I., 2002. Cultivo do milho: manejo integrado de pragas. Sete Lagoas: Embrapa Milho e Sorgo. Comunicado Técnico, no. 50.

YAMASHITA, S., ANDO, A., HOSHINA, H., ITO, N., KATAYAMA, Y., KAWANABE, M., MARUYAMA, M. and ITIOKA, T., 2015. Food web structure of the fungivorous insect community on bracket fungi in a Bornean tropical rain forest. Ecological Entomology, vol. 40, no. 4, pp. 390-400. http://dx.doi.org/10.1111/een.12200. 